\title{
3 Research Square \\ Hybridizing research and decision-making: a path toward sustainability in marine spaces
}

Catherine Boemare ( $\nabla$ catherine.boemare@ehess.fr)

École des Hautes Études en Sciences Sociales

Elsa Mosseri

French National Centre for Scientific Research

Grégory Agin

Gulf of Lions Marine Park

Lorenzo Bramanti

French National Centre for Scientific Research

Raphaël Certain

University of Perpignan

Joachim Claudet

French National Centre for Scientific Research

Katell Guizien

French National Centre for Scientific Research

Coraline Jabouin

Gulf of Lions Marine Park

Xavier Lagurgue

École Nationale Supérieure d'Architecture Paris-Val de Seine

Philippe Lenfant

University of Perpignan

Harold Levrel

Université de Paris Saclay

Charlotte Michel

Usages et Territoires

Olivier Musard

Gulf of Lions Marine Park

Marion Verdoit-Jarraya

University of Perpignan

Article

Keywords:

Posted Date: February 23rd, 2022 
DOI: https://doi.org/10.21203/rs.3.rs-1374903/v1

License: (c) (i) This work is licensed under a Creative Commons Attribution 4.0 International License. Read Full License 


\section{Abstract}

Projecting the combined effect of management options and the evolving climate is necessary to inform shared sustainable futures for marine activities and biodiversity. However, engaging multi-sectoral stakeholders in biodiversity-use scenarios analysis remains a challenge. Using a marine social-ecological case study, we coupled co-designed visioning narratives at the horizon 2050 with an ecosystem-based model. Our analysis revealed a mismatch between the stated vision endpoints at 2050 and the model predictions narrative objectives. However, the discussions that arose from the approach opened the way for previously unidentified transformative pathways. Hybridizing research and decision-making with iterative collaborative modelling frameworks can enhance adaptive management policies, levering paths toward sustainability.

\section{Introduction}

The ocean largely contributes to human wellbeing but is increasingly threatened by human action and climate change [1]. Marine Protected Areas (MPA) are advocated as a key strategy for simultaneously protecting biodiversity and supporting coastal livelihoods [2,3]. They are now part of the Convention on Biological Diversity and the Sustainable Development Goals. Their level of protection encompasses fully protected areas where all activities are prohibited to a range of "partially protected MPA" that allow activities to different degrees $[4,5]$. The formers are known to deliver ecological benefits $[6,7,8]$ whereas the latter assume that conservation will be achieved through cooperation in the social space [9].

While scientific evidence shows that most benefits including biodiversity conservation, food provisioning and carbon storage stem from fully or highly protected areas, most established MPA are of lower protection levels because of lobbying from current users and political bias towards creating many rather than highly protected areas $[6,7,8,10]$. Thus, potential benefits and beneficiaries have to be highlighted and understood at a local level to discuss trade-offs and address the ecological, social and economic requirements of sustainability.

However, guiding principles are lacking on how to manage trade-offs in specific social-ecological systems (SES) [11]. Even if conceptual models of SES have been elaborated to characterize human-nature interactions and inform decision-making $[12,13,14,15,16,17,18]$, effective science-policy interfaces in marine environments are scant [8].

There is room for more effective and inclusive science-policy frameworks, including dedicated modelling approaches. Each step of a collaborative prospective modelling from elaborating narratives to interpreting simulation results, including model conception, may help exploring ecological, social and economic consequences of management alternatives at a local level and in the context of on-going climate change.

For decision-makers, there is a growing awareness that integrating valuable scientific knowledge and stakeholders during the management process can offer better outcomes $[19,20,21,22,23,24,25,26]$ and is less likely to result in the collapse of the resource $[27,28]$. But it raises three main challenges for science. First, collaboratively develop narratives that break with the usual approach based on ongoing trends, which 
has failed to mobilize transformative change [29]. Second, shift from resources toward ecosystem-based management, addressing interactions among scales within SES [30]. Third, better align the modelling practice illustrating trade-offs with the decision-making process ultimately setting management rules [19].

We argue that bridging the gap between what the literature recommends and what is done on the field requires an innovative science-policy framework which identify potential benefits, tackles necessary tradeoffs and promotes collective deliberation on management goals and rules. To test this, we hybridized research and decision-making through collaborative prospective modelling in the case of a French Mediterranean marine park. Hence, scientists, policy-makers and stakeholders involved in the management of the MPA conducted this research. Here, we describe how we were collectively able to (i) build contrasting narratives for the future addressing biodiversity conservation, food provisioning and economic activity in the context of climate change; (ii) explore resulting strategies with a science-based SES model illustrating tradeoffs; (iii) share common understandings of management issues and raise new concerns.

\section{Findings}

Building disruptive narratives to open the range of possible futures (342 words).

Very recent scientific works suggest that we need to move beyond classical scientific studies depicting future trajectories of decline which have failed to mobilize transformative change [19]. Exploring different futures through narrative scenarios prove to be helpful to address MPA management issues in a constructive manner [31]. Lubchenco and Gaines notably emphasize how narratives help in framing our thinking and action [32]. Indeed, like in mythology or literature, these act as a reference frame to which one can refer to make decisions adapted to unpredicted but pictured context. Here, the challenge is to extend or amend our reference scheme by imagining transformative futures.

In our project we did so by inviting scientists, stakeholders and decision-makers to participate in three workshops led by a specialist in building prospective scenarios. Each time, participants were split into three groups for progressively writing a narrative about the Gulf of Lion Marine Natural Park by 2050. It led to the writing of three original and transformative narratives (table 1). 2050 was considered close enough to fit with real political deadline, i.e., the completion of two management plans, and far enough to deal with some expected effects of climate change so as the decline of primary production in marine ecosystems.

Each group focused on fostering one of the three ecosystem service considered: regulation, provisioning or cultural ecosystem service. Ecosystem services are acceptable indicators to assess MPA sustainability in providing a common semantic for all participants with diverse backgrounds. They allow to work on interactions between biodiversity conservation and economic development. Proxys used and related to ecosystem services are also aligned with the ones used in the park management plan, which helps for science-policy dialogue.

To reach the objectives of the narratives, participants were especially requested to give indications about considering climate change impact or not, fishing effort evolution, spatial sea-users' rights (FPA), facilities planning (artificial reefs, floating wind turbines, harbors and breakwaters, multi-purpose facilities) and 
ecological engineering (reintroduction of species), the main features of the socio-ecological representation on which we all agreed (see figure 1). [see methods A].

\section{Table 1 - Co-designed visioning narratives built in workshops}


Narrative 1: protecting the ecological heritage and strengthening the marine food web in order to promote regulation ecosystem services.

Starting_point: it reports the progressive deficiency of top predators and keystone species (grouper, sharks...) and its corollary: the impoverishment of the whole trophic chain [59]. But this scenario considers the uncertainties surrounding the idea of good ecological status [60] and shifting baselines $[60,61,62]$. Hence, specifying an ideal ecological state to achieve didn't make so much sense for the participants, who focused on preserving key habitats, keystone species, and enhancing the actual food chain [63]. This strategy was inspired by the ecological concept: the more diversity there is, the greater the resilience of the system $[64,65]$.

Climate change

Decline of primary production in marine ecosystems

Fisheries
Constant fishing effort
but no fishing on existing
reefs \& in fully protected
areas
Diving
Constant number of
divers but no access to
fully protected areas

Management rules: the participants imagined extending full protection up to $30 \%$ of the MPA. This ratio was chosen to echo the most ambitious existing target worldwide: the International Union for the Conservation of Nature recommendation that at least $30 \%$ of the entire ocean should benefit from strong protection. Participants also proposed stabilizing fishing effort and re-introducing top predators like groupers in the suitable habitats.

Fully_protected
Leas
Level:
most ambitious
existing target
Location:
most important
natural areas all
over the rea

Fully_protected

Level:

most ambitious

natural areas all over the rea
Facilities \&
ecological
engineering

- No development but no removal of artificial reefs

- Acceptation of a small experimental wind farm to evaluate its impacts

- Reintroduction of heritage species

\section{Narrative 2: upgrading the artisanal fishery in order to promote food provisioning ecosystem services.}

Starting point: it is a strong awareness among the members of the group of the climate change expected consequences on marine primary production, being the first level of the food chain $[66,67]$. They figured a decline of primary production due to climate change may be driven by the decrease of nutrients flows due to dams on rivers and partial closure of estuaries. In order to increase the biomass of commercial species, stakeholders proposed actions to be taken on land to avoid the expected decline of marine primary production. They also got inspired by "slow food" movements and invented a "slow fishing" style, in the sense that fishing should respect life cycles of different species and marine habitats, in terms of harvesting gears and anchoring systems. It would still be profitable enough for fishermen because the products would be eco-labeled and valued as such.

Climate change

Decline of primary production in marine ecosystems counterbalanced by improved circulation between lagoons, rivers and sea

\section{Fisheries}

Increased fishing effort but no fishing on any reefs \& in fully protected areas

Diving
Management rules: only this narrative allows increasing the fishing effort while artificial reefs for productive purpose are favored and commercial species are reintroduced. The share of fully protected areas is kept to current level ( $2 \%$ of the MPA). Climate change leads to a decline of primary production in marine ecosystems, that would be counterbalanced by a spatial development improving the circulations between lagoons, rivers and sea.

\section{Fully_protected areas \\ Level: \\ actual MPA's target}

Location:
Facilities \& ecological engineering

- Increased density of existing artificial reefs villages and creation of new reefs 
Constant number of divers but no access to

fully protected areas most important natural areas surrounding the existing marine reserve
- Development of a commercial wind farm

- Reintroduction of commercial species

\section{Narrative 3: fostering a new economy promoting cultural ecosystem services.}

Starting_point: it lies in the climate change expected consequences on the coastline and the consideration of a possible radical transformation in coastal livelihoods due to the loss of biomass of the sea induced by a primary production decrease [67]. Even if the sea level rise consequences exceeded our time frame, participants considered it as a major driver of change. They presumed management would fail to prevent sea level rise and decided to put their efforts in making the best of the new resulting land/sea-scape. They invented a new economic model for the park area, valuing marine underwater seascapes, eco-friendly tourism around artificial reefs and wind turbines, or even an underwater museum around aesthetical artificial reefs.

Management rules: participants assumed a commercial wind farm would be created allowing for a multifunctional exploitation of the water column, including educational sea trips. Artificial reefs villages would be densified to create a relief zone for the rocky coast diving sites. These reefs would have a cultural function, like an underwater museum. Their design would rely on ecological and aesthetical requirements. An intermediary target for fully protected areas was set after Member States Parties to the Convention on Biological Diversity (CBD) agreement to cover $10 \%$ of their coastal and marine areas with MPAs by 2020 (CBD Aïchi target 11). Climate change
Decline of primary production
in marine ecosystems

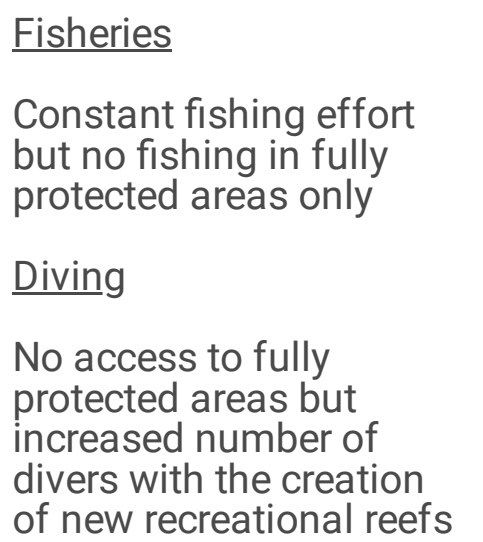
Fully_protected areas
Level:
intermediary
target
Location:
most important natural areas but first those surrounding the existing marine reserve

$$
\begin{aligned}
& \text { Facilities \& } \\
& \text { ecological } \\
& \text { engineering }
\end{aligned}
$$

- Increased density of existing artificial reefs villages and creation of new recreational reefs

- Development of a
commercial wind
farm
- Sea trips around
the farm \& diving
around recreational
reefs

- No reintroduction of species

\section{Ecosystem-based modelling to address SES complexity (638 words)}

Tackling the whole issues marine spaces are confronted to requires MPA managers to adopt an integrated Ecosystem Based Management (EBM) that considers the entire ecosystem, including humans. While fishing affects target species, marine food-webs and habitats (depending on fishing and anchoring gears), climate change is expected to influence the dynamics of all marine organisms in terms of growth and spatial distribution (including primary production). 
EBM focuses on maintaining a healthy, productive and resilient ecosystem so it provides the services humans want and need. It requires transdisciplinary approach that encompasses both the natural dimension of ecosystems and the social aspects of drivers, impacts and regulation [33].

Whether "end-to-end models" are recommended by marine scientists to study the combined effects of fishing and climate change on marine ecosystems, using one of these tools was beyond the scope of the project [see methods B]. We looked for alternative ways and built on knowledge and data from the park management plan and on past research conducted on the area: ecosystem-based quality indexes (EBQI) describing the functioning of specific ecosystems and mass-balance models analyzing the overall ecosystem structure and fishing impacts (Ecopath with Ecosim) [see methods C].

We map four major park habitats (see figure 2): "sandy\&mud" (31 species), "rock" (18 species), "posidonia" (17 species), "coralligenous" (15 species). Here (group of) species are represented in aggregate form (biomass density) and linked together with diet ratios (see table SM2 a-d).

This ecosystem-based representation is at the core of our modelling exercise. To simulate ecosystem dynamics, we used the ecosystems food-webs as transmission chains for the type of controlling factors described in the narratives [34]: bottom-up control (climate, management), top-down control (fisheries, management). For each (group of) species, biomass variation results from the equal combination of two potential drivers on a yearly basis: the abundance of prey (bottom-up control, positive feedback) and the abundance of predators (top-down control, negative feedback) [see methods D].

To link this food-web modelling with the driving factors described in the narratives, we adopted an agentbased modeling (ABM) framework. ABM are already used for SES applications and science-policy dialogue [see methods $\mathrm{E}$ ].

We then developed a spatially explicit model for the main dimensions of the MPA described in the narratives. To set up agents and their environments, we used data from the ecosystem-based representation and geographic information systems (GIS) layers provided by the MPA team. To model space, we used a regular grid, the size of each cell being related to the average size of an artificial reef village $\left(0,25 \mathrm{~km}^{2}\right)$. In accordance with our prospective horizon, simulations ran by 2050 with an annual time step.

The food-web model is located at the cell level with previous year's outputs as input data for each new year. Other human and non-human agents are also represented at the cell level. At this stage we model temporal dynamics but lack important spatial dynamics such as adaptive behaviors of human and non-human agents re-locating their activities as a result of management measures. For now, interactions between agents are mostly made of spatial-temporal co-occurrence with restricted mobility.

Despite this, we were able to simulate the variation of any group of species in terms of biomass density in case of a change in primary production, fishing effort, artificial reefs planning or reintroduction of species. In order to disentangle the efficacy of the MPA's management measures from climate change impact, we ran each scenario with and without climate change (figure 3 ). Indeed, the variation of primary production is the only difference between scenarios that does not depend on management choices at the MPA's level. We 
could capture some of their propagation and final effects on indicators similar to those of the park management plan and the ecosystem services targeted by the narratives: total biomass (regulation services); harvested biomass (provisioning services); diving sites access (cultural services) [see methods F].

Discussing simulation results to inform management choices (1351 words).

No scenario perfectly reaches the objectives it was designed for (Figure 3). However, they all draw interesting perspectives like the occurrence of unexpected co-benefits. The framework we built allows i) looking at the building blocks of the scenarios and the combination of variables so as to explain the results, ii) proposing explanations and suggesting new hypotheses for enhancing the efficacy of each scenario.

Table 2 summarizes the major assumptions of the three scenarios issued by the project team from the narratives.

Table 2 - Overview of the three scenarios 


\begin{tabular}{|c|c|c|c|c|}
\hline Topic & Item & $\begin{array}{l}\text { Scenario } 1 \text { - } \\
\text { enhancing regulating } \\
\text { services }\end{array}$ & $\begin{array}{l}\text { Scenario } 2 \text { - } \\
\text { enhancing provisioning } \\
\text { services }\end{array}$ & $\begin{array}{l}\text { Scenario } 3 \text { - } \\
\text { enhancing cultural } \\
\text { services }\end{array}$ \\
\hline $\begin{array}{l}\text { Climate } \\
\text { change - } \\
\text { impact on } \\
\text { primary } \\
\text { production }\end{array}$ & $\begin{array}{l}\text { Phytoplankton } \\
\text { biomass } \\
\text { density }\end{array}$ & $\begin{array}{l}\text { steady decrease up } \\
\text { to }-4 \% \text { by } 2050\end{array}$ & stable & $\begin{array}{l}\text { steady decrease } \\
\text { up to }-4 \% \text { by } 2050\end{array}$ \\
\hline \multirow{5}{*}{$\begin{array}{l}\text { Sea-users - } \\
\text { fisheries }\end{array}$} & Fishing effort & stable & $5 \%$ increase from 2019 & stable \\
\hline & Practice area & \multirow{2}{*}{\multicolumn{3}{|c|}{$\begin{array}{l}\text { artisanal fisheries: } 0 \text { to }-200 \text { meters; } 0 \text { to } 6 \text { miles } \\
\text { trawls: prohibited between } 0 \text { to } 3 \text { miles }\end{array}$}} \\
\hline & & & & \\
\hline & Access rights & \multirow{2}{*}{\multicolumn{3}{|c|}{$\begin{array}{l}\text { no fishing in FPA } \\
\text { no transfer to others areas }\end{array}$}} \\
\hline & & & & \\
\hline \multirow[t]{4}{*}{$\begin{array}{l}\text { Sea-users - } \\
\text { diving }\end{array}$} & $\begin{array}{l}\text { Number of } \\
\text { divers }\end{array}$ & stable & & \\
\hline & Practice area & \multicolumn{3}{|c|}{ most popular diving sites (GIS) } \\
\hline & $\begin{array}{l}\text { Access rights } \\
\text { to FPA }\end{array}$ & \multirow{2}{*}{\multicolumn{3}{|c|}{$\begin{array}{l}\text { no diving in FPA } \\
\text { no transfer to others areas }\end{array}$}} \\
\hline & & & & \\
\hline \multirow[t]{5}{*}{$\begin{array}{l}\text { Management } \\
\text {-FPA }\end{array}$} & $\begin{array}{l}\text { Share of FPA } \\
\text { in the MPA }\end{array}$ & $\begin{array}{l}30 \% \text { by } 2050 \text { after } \\
\text { extensions in } \\
2020 / 2025 / 2030\end{array}$ & $\begin{array}{l}2 \% \text { by } 2050 \text { after } \\
\text { extensions in } \\
2020 / 2025 / 2030\end{array}$ & $\begin{array}{l}10 \% \text { by } 2050 \text { after } \\
\text { extensions in } \\
2020 / 2025 / 2030\end{array}$ \\
\hline & Location & \multicolumn{3}{|c|}{1 existing marine reserve (GIS) } \\
\hline & & \multicolumn{3}{|c|}{ new FPA: GIS layer scaling important natural areas } \\
\hline & Allocation rule & overall extension & extension around the & 2020: scenario 1 \\
\hline & & natural value & existinig leselve & $\begin{array}{l}\text { 2025/2030: } \\
\text { scenarios } 1 \& 2\end{array}$ \\
\hline \multirow[t]{3}{*}{$\begin{array}{l}\text { Management } \\
\text { - artificial } \\
\text { reefs }\end{array}$} & $\begin{array}{l}\text { Density of } \\
\text { existing } \\
\text { artificial reefs } \\
\text { villages }\end{array}$ & stable & \multicolumn{2}{|c|}{$\begin{array}{l}\text { steady increase from } 12 \% \text { to } 50 \% \text { between } \\
2019 \text { and } 2050\end{array}$} \\
\hline & New & no & \multirow{2}{*}{\multicolumn{2}{|c|}{$\begin{array}{l}\text { from sandy habitat to rocky habitat with a } \\
\text { density of } 50 \% \\
\text { colonization by marine organisms following } \\
\text { three steps between } 2019 \text { and } 2024\end{array}$}} \\
\hline & villages & & & \\
\hline \multirow{3}{*}{$\begin{array}{l}\text { Management } \\
\text { - floating } \\
\text { wind } \\
\text { turbines }\end{array}$} & Type of farm & $\begin{array}{l}\text { experimental farm of } \\
4 \text { turbines }\end{array}$ & \multicolumn{2}{|c|}{ commercial farm of 80 turbines } \\
\hline & Location & \multicolumn{3}{|c|}{ map of feasible and acceptable areas } \\
\hline & Allocation rule & \multicolumn{3}{|c|}{$\begin{array}{l}\text { development every five years between } 2020 \text { and } 2045 \text { around more or } \\
\text { less acceptable areas }\end{array}$} \\
\hline
\end{tabular}




\begin{tabular}{|lllll|}
$\begin{array}{l}\text { Management } \\
\text { - multi- } \\
\text { purpose } \\
\text { facilities }\end{array}$ & $\begin{array}{l}\text { Sea trips } \\
\text { around the } \\
\text { commercial } \\
\text { farm }\end{array}$ & no & no & $\begin{array}{l}\text { visitor attendance } \\
\text { follows from the } \\
\text { development of } \\
\text { the farm }\end{array}$ \\
\cline { 2 - 6 } & $\begin{array}{l}\text { Diving around } \\
\text { recreational } \\
\text { reefs }\end{array}$ & no & no & $\begin{array}{l}\text { visitor attendance } \\
\text { follows from the } \\
\text { development of } \\
\text { recreational reefs }\end{array}$ \\
\hline $\begin{array}{l}\text { Management } \\
\text { ecological } \\
\text { engineering }\end{array}$ & $\begin{array}{l}\text { Reintroduction } \\
\text { of species in } \\
\text { existing } \\
\text { artificial reefs } \\
\text { villages }\end{array}$ & $\begin{array}{l}2020-2025 \text { : annual } \\
\text { release of } 1 \text { heritage } \\
\text { specie (grouper) }\end{array}$ & $\begin{array}{l}\text { 2020-2025: annual } \\
\text { release of } 2 \\
\text { commercial species } \\
\text { (seabass, dentex) }\end{array}$ & no \\
\hline
\end{tabular}

Scenario 1 aimed at increasing biodiversity. Simulation results show that (see SM1):

- Undersea biomass varied little $(-0.11 \%)$, despite the primary production decrease under climate change. Yet, the trophic chain structure changes with huge increase of species important in local fisheries (see biomass variation of each group in SM6 a-e). Mackerel, whiting, hake and tuna but also octopuses and soles notably increase in the muddy and sandy ecosystems; octopuses, seabass but also echinoderms and bivalves and gastropods in the coralligenous ecosystem; echinoderms, octopuses and conger in the rocky ecosystem; suprabenthos, echinoderms, octopuses, conger and scorpion fish in the posidonia ecosystem. The increase in the above listed species is balanced due to the double preys/predators constraint by a decrease in the biomass of other existing species: benthic invertebrates and fish feeding on benthic crustaceans in the muddy and sandy ecosystems; benthic macrophytes, scorpion fish, suprabenthos and lobsters in the coralligenous ecosystem; suprabenthos, salema, seabass and scorpion fish in the rocky ecosystem; andworse- posidonia itself, salema and crabs in the posidonia ecosystem.

- Fished biomass drops by $36 \%$ which is consistent with the high share of FPA in the absence of spatial dynamics and fishing effort relocation.

- Currently appealing diving site will no longer be accessible (-98\%) which is expected to support habitats and species biomass regeneration but would mark the end of an attractive activity.

Hence, scenario 1 proposed an extension of FPA up to $30 \%$ and located it on the richest areas in terms of biodiversity, which leads to a sharp drop in potential fished biomass indicator. This strong protection may not be sufficient to trigger the system recovery as a whole but greatly change the trophic chain structure improving the biomass of some very important fishing targeted species (see SM6 a-e). This improvement could be seen as a co-benefit aligned with Sala \& al., analysis [10]. It opens avenues to move forward searching for "win-win" strategies and opens a perspective of occurring co-benefits for local fisheries in case of spillovers would occur and adequate fisheries management rules were to be defined.

Moreover, if coupled with the same kind of measures allowing to cancel the negative effect of climate change on primary production as in scenario 2 , this scenario would exhibit the best results in terms of total and undersea biomass variation- although these indicators alone are insufficient to assess the quality of the ecosystem. 
Hence, two hypotheses could be tested: the time horizon may not be sufficient, and/or the intensity of the reintroduction of the keystone species, grouper, is insufficient given the low reproduction rate and longevity of the species. Whatever, it would be interesting to review this scenario searching co-benefits strategies. A new version of the model could test pairing spatial uses rights and different level of protection within a strategic zoning and a connected MPAs network. It would also consider the spillover of marine organisms and the relocation of human activities due to FPA. In this case, would the spillover of marine species be enough so that the relocation of the fishing effort wouldn't affect too much ecosystem functioning of unprotected areas? In a timely manner, additional measures regulating the fishing effort in a strategic planning/zoning perspective would complement the framework.

Scenario 2 aimed at increasing food provisioning. Simulation results show that:

- Total fished biomass increases by $2 \%$ with or without taking into account the climate change impact on primary production, which matches the guideline of the narrative. However, fished biomass increases only in the muddy habitat, by more than $3 \%$, while it decreases by between -3 and $-32 \%$ in the other habitats, as a result of the counterbalancing effect of keeping the $2 \%$ share of FPA. Interestingly, the total biomass in the rocky habitat decreases less (with climate change) or even increases (without climate change) in scenario 2 compared to scenario 1.

- Undersea biomass seems stable when climate change is not included (-0.03\%) but will decrease with primary production $(-0.89 \%)$, in contrast with scenario 1 . Compared with scenario 1 , few species show significant downward variation, except crabs in the posidonia ecosystem.

- Even with the smallest FPA's share, currently appealing diving sites are reduced by $63 \%$, which confirms that most existing diving spots are concentrated on areas of high natural value in or around the existing marine reserve of the MPA.

Scenario 2 favors fishing by increasing fishing effort (5\%) and limiting FPA (2\%). It also supports fishing with the reintroduction of target species and the densification of these species' habitats. This scenario notably avoids the negative effect of climate change on primary production thanks to ecological measures taken at the watershed level. However comparative simulation results illustrate that the marine park management measures alone would not generate such an effect. In view of the results, the fishing effort may have been increased too early, thereby cancelling out the efforts made elsewhere. Moreover, catches might have been higher if the model had considered a shift of fishing activities from FPA to areas where fishing is allowed. Here, FPA are located on rocky, posidonia, and coralligenous habitats, that are areas of greatest natural value. Even if the share of FPA is the lowest in this scenario, almost all of the rocky habitat (excluding artificial reefs) is concerned, which is one reason explaining the biomass increase in this habitat. This shows the importance of a precise and strategic zoning in determining access rules in MPAs. This is also due to the densification of existing villages and the creation of new villages in the rocky habitat.

Two new hypotheses could then be tested: maintaining the fishing effort at its 2018 level and increasing the introduction of target species? Working more on the dynamics of the trophic chain by reintroducing keystone species rather than target species? 
Scenario 3 aimed at increasing eco-tourism. Simulation results illustrate that:

- The main objective of the scenario is not achieved since diving access is restricted by 100 and $91 \%$ in the coralligenous and rocky habitats, that host most currently appealing diving sites.

- Undersea biomass (and total biomass) declines more than in scenario $1(-0.6 \%)$, but less than in scenario 2 in the same climatic context of primary production reduction, reflecting the difference in FPA cover of the different scenarios. Interestingly, despite taking for granted the loss of historical ecosystems and traditional economic activities and including primary production reduction, the total biomass increases by $0.12 \%$ in the rocky habitat, which is again a better score than what scenario 1 reached.

- Fished biomass lowers by $14 \%$, due to a $10 \%$ FPA's share, and in accordance with a narrative that promotes the creation of alternative economic activities.

Scenario 3 is the scenario that produces the most spectacular results since diving sites access is in sharp decrease whereas it is supposed to favor cultural services.

These results' explanation lies in a contradiction between the assumptions of the narrative. In fact, by placing $10 \%$ of the territory under full protection and locating these areas on sites of high biodiversity, FPA are located on the very sites favored by divers. This contradiction between the goal of this narrative and the restricted access to FPA proves to be a determining factor in the success of the policy. Retrospectively, this may seem obvious but the exact delimitation of access rules to protected areas remains a hot topic. After all, this scenario is interesting because it illustrates an actual dilemma and confirms scenario 2 analysis that access rules need to be aligned and defined with a precise and strategic zoning.

We could then try another hypothesis allowing recreational diving access to FPA while extractive activities remain prohibited.

\section{Discussion}

In this paper, we showed the usefulness of a three (+one) steps framework hybridizing a collaborative modelling approach and a decision-making process (see figure 4) as a way of identifying the future desired in a marine protected area and the way to get to it. Indeed, the framework proposed allows discussing about hypothesis concerning the future of the area, which enables reshaping our thinking and to eventually framing new strategies. The framework acts as a dialogue space for people concerned with the SES and willing to support the implementation of the management plan. This dialogue space offers the possibility to realize that there is a difference between expectations and the complexity of reality. Indeed, simulation results did not always illustrate expected effects of the narratives. In this respect, our method paves the way for questioning our beliefs as long as stakeholders are involved. The science-policy prospective experiments we conducted considered placed-based issues, participants knowledge and imaginaries. Scientists coming from ecology and social sciences, decision-makers and stakeholders of the MPA found the approach groundbreaking. Hence, by opening the box of scriptwriting scenarios, we experienced a way for constructing new narratives and broadening the solution space for ocean as requested by Lubchenko and Gaines [32]. 
Similar collaborative approaches have been developed by the Commod community [18]. Ours is original in it occurs for anticipating and creating common future rather than to resolve actual conflicts like the Commod ones.

Hence, it fosters anticipatory governance capacity by testing assumptions, understanding interdependencies, and sparking discussions in order to avoid that policy makers acting in their own jurisdiction generate spillovers that modify evolution pathways of related SES or constrain adaptive capacity of other policymakers [35]. Lack of coordination between policy actors across jurisdictions, incomplete analysis of potential cascading effects in complex policy contexts can lead to maladaptation [35]. In this regard, our framework can participate in addressing those challenges a marine park was designed to face, being a social construction that has to build on historical heritage and be invested by new common means in order to reach legitimacy and deliver acceptable sustainable policies.

We also built a framework allowing to collaboratively explore impacts of alternative management scenarios on marine SES considering climate change, identifying benefits and beneficiaries and resulting trade-offs among ecosystem services. This experience led us to interesting conclusions which arose from the simulations results themselves. Those latter showed that co-benefits may arise and be favored by a precise and coherent system of rules of access and uses complementing a more physical, biological and ecological set of measures. Our findings show that some trade-offs may satisfy several objectives, even when not those targeted first, opening the way to potential co-benefits as shown by [10]. For instance, the strong protection extension in scenario 1 greatly changed the trophic chain structure, improving the biomass of some very important fished species, opening avenues to move forward searching for "win-win" strategies. Similarly, measures allowing to cancel the negative effect of climate change on primary production proposed in the scenario 2 would increase the total biomass together with maintaining biodiversity in scenario 1.

More generally, this research developed a companion modelling framework that would enable to move forward in the search for win-win strategies by pairing strategic zoning of high protection and rules of access. For this to be the case, some improvements are needed. There are avenues. For example, improving the modelling tool by describing spatio-temporal dynamics arising from the spillover of marine organisms [36], the resilience brought by population connectivity [37] and the relocation of human activities [38].

Finally, this research suggests that the management of the marine environment should be an inclusive, iterative process where modelling acts as a continuous exploratory experiment searching for win-win strategies. Hence, the modelling process facilitate interactions between participants in a transparent and open process. One can thus imagine working sequentially until satisfactory results are obtained for any stakeholder involved. This search for hybridized collaboration framework in the construction of policies proves particularly fruitful in creating common future and looking for sustainability.

\section{Methods}

[A] Materials used during the prospective workshops. For fostering envisioning disruptive changes, we decided to draw on possible future land/seascapes of the MPA. To shape them, we introduced visual tools 
during the prospective workshops (see SM7):

i. an archetypal map of the MPA including typical features to recall main territorial issues without being trapped in too specific considerations: a city by the sea, the mouth of a river, an estuary, a rocky coast, a sandy coast;

ii. tokens related to the available means to reach the narratives' objectives: ecosystems status (primary production), fisheries evolution (fishing effort), facilities planning \& ecological engineering (esthetical artificial reefs, floating wind turbines, harbors and break walls, reintroduction of species), sea-users' access and regulation (recreational uses and fully protected areas). Tokens were used to inform about localization and intensity of each item, which helped shaping participant's vision of the future and linking with the simulation model.

iii. cards describing real world examples of what tokens stand for. They were used to broaden the participant's thinking scope introducing stories in foreign places and different times. Here they helped illustrating alternative options among scenarios.

[B] Overview of end-to-end models. End-to-end models represent the different ecosystem components from primary producers to top predators, linked through trophic interactions and affected by abiotic environment [39]. They allow studying the combined effects of fishing and climate change on marine ecosystems coupling hydrodynamic, biogeochemical, biological and fisheries models. Some are suited to explore the impact of management measures on fisheries dynamics with an explicit description of fishing stocks spatial and seasonal dynamics, fishing activities and access rights (ISIS-Fish) [40, 41, 42]. But they don't represent environmental conditions or trophic interactions so their capacity to simulate the impact of fisheries management on ecosystem dynamics and possible feedbacks is limited.

Others explicitly model trophic interactions between uniform ecological groups with biomass flows based on diet matrixes (Ecopath with Ecosim [43], Atlantis). They rely on the assumption that major features of marine ecosystems depend on their trophic structure, thus there is no need to detail each species to describe the state and dynamics of the ecosystem. They can be used to explore the evolution of the system under variations in biological or fishery conditions but may lack flexibility to simulate regime shifts due to radical variations of such conditions.

Some others do not set a priori trophic interactions, which are considered too rigid to explore the non-linear effects of both fishing and change in primary production. They describe predation as an opportunistic process that depends on spatial co-occurrence and size adequacy between a predator and its prey (OSMOSE). Thanks to the simulation of emergent trophic interactions, they are particularly relevant to explore the single or combined effects of fishing, management and climate change on the ecosystem dynamics. But they do not properly describe fisheries dynamics (fixed fishing mortality) and must be coupled with fleet dynamics models (dynamic effort allocation) [44].

[C] Research works used for ecosystems description. First, we selected three publications describing the specific ecosystems functioning associated with marine park habitats: the Mediterranean seagrass ecosystem [45], the coralligenous ecosystem [46] and the algae-dominated rocky reef ecosystem [47]. 
Second, we selected two publications using a same mass-balance model (EwE) to analyze the overall ecosystem structure and fishing impacts in respectively the Gulf of Lion [48] and the northwestern Mediterranean Sea [49]. They both provide a snapshot of the trophic flows in the ecosystem during a given period, that is based on a consistent set of detailed data for each group of species: biomass density, food requirements (diet matrix), mortality by predation and by fishing, etc. The former focuses on the Gulf of Lion but depicts a bigger area than that of the park in terms of distance to the shore and especially depth (- 2500 $\mathrm{m}$ against $-1200 \mathrm{~m}$ ). Thus, the rocky reef ecosystem that exists within the park is "masked" by the prevalence of sandy/muddy habitats. The later depicts a wider part of the Mediterranean Sea but is comparable to the park in terms of depth $(-1000 \mathrm{~m}$ against $-1200 \mathrm{~m})$ and provides useful information on the rocky reef ecosystem.

Each ecosystem represents the following proportion of the whole system: muddy $=85.57 \%$, sandy $=12.23 \%$, rocky $=1.75$, posidonia $=0.23$ and coralligenous $=0.22 \%$. For "rocky", "posidonia" and "coralligenous", we selected corresponding ecological groups and associated data (Ewe) from functional compartments (EBQI). For "sandy\&muddy" we created an ad-hoc conceptual model of the ecosystem functioning from the Gulf of Lion trophic chain (Ewe).

[D] Food-web modelling. For each related group of species, the variation of the average density results from the equal combination of two potential drivers on a yearly basis: the abundance of prey (bottom-up control, positive feedback) and the abundance of predators (top-down control, negative feedback). To do so, we use data from the EwE publications listed above: biomass density, food requirements (diet matrix), mortality by predation and by fishing. For one species, the White gorgonian (Eunicella Singularis), we use site-specific data produced during the RocConnect project [50].

To model the effect of prey abundance on their predators, the biomass of each group of species is described as the sum of its annual food requirements, detailing each prey (see SM3). While nothing happens to a prey species, there is no change in prey abundance and the biomass of each predator's species remains the same. If anything happens to a prey species, this translates into that species density, then reflects in its availability for feeding predators, and eventually affects the biomass of predator's species. The effect on the biomass of predator's species is proportional to the change in prey species density and to the specific weight of prey species in each predator's diet. In other words, the more prey there is at the beginning of the period, the more of its predators there could be at the end.

To model the effect of predator's abundance on their prey, we follow the reciprocal reasoning of the above mechanism. Here the biomass of each group of species is described as the sum of its annual catches by each other species. Here again, while nothing happens to a predator's species, there is no change in predator's abundance and the biomass of each prey species remains the same. If anything happens to a predator's species, this translates into that species density, then reflects in its food requirements, and eventually affects the biomass of prey species. But this time, the effect on the biomass of prey species is inversely proportional to the change in predator's species density and to the specific weight of predator's species in each prey's mortality. In other words, the more predators there are at the beginning of the period, the less of its prey there could be at the end. 
There are only two exceptions to this rule: phytoplankton and detritus. The production of phytoplankton relies on photosynthesis which needs water, light, carbon dioxide and mineral nutrients. These elements are beyond our representation, so we rather impose the value of the phytoplankton biomass density at each time step. Also, the value of phytoplankton biomass density is the variable used to represent the expected effect of climate change on primary production. The production of detritus comes from three sources: natural detritus, discards and by-catch of sea turtles, seabirds and cetaceans. In other words, the amount of detritus depends on the activity of other marine organisms. Here we model the amount of detritus as a constant share of the total annual biomass.

[E] The rationale for ABM. Most studies on MPA analyze how they succeed from an ecological point of view [48]. Few others argue about the conditions under which they succeed from a socio-economical or cultural point of view. Little work embraces both aspects of MPA. Now, ABM are convenient methods to integrate ecological and socio-economical dynamics and are already used by researchers in ecology or economics for ecosystem management $[51,52,53]$. Agent-based models (ABM) allow considering any kind of agents with different functioning and organization levels [54, 55], here human activities, marine food-webs and facilities planning. $A B M$ are also usually spatially explicit which favors connecting with narratives that are spatially explicit too. Basically, an agent is a computer system that is located in an environment and that is acting autonomously in order to meet its objectives. Here environment means any natural and/or social phenomena that has potentially an impact on the agent.

For these reasons, ABM are convenient methods to deal with SES. The possibility of providing each kind of agent with a representation of the environment, according to specific perception criteria, is particularly interesting for applications in the field of renewable resources management [18]. ABM developed for SES management usually integrate an explicit representation of space: a grid with each cell corresponding to a homogeneous portion of space. Time is generally segmented into regular time steps. The simulation horizon (total time steps) corresponds to the prospective horizon.

\section{[F] Modelling of drivers and indicators of ecosystem status.}

\section{Climate change.}

To model the expected effect of climate change on primary production, we build on IPCC projections that consider a $10 \%$ to $20 \%$ decrease of net primary production under low latitudes by 2100 , due to reduced vertical nutrient supply $[56,57]$. Applied to our simulation horizon, this can be translated into an annual steady decrease up to $-4 \%$ in phytoplankton biomass density between 2018 and 2050 .

Sea users. Fisheries.

To model fisheries, we use the same rule as to model the effect of predator's abundance on their prey, but here this represents the effect of fishing effort on harvested species. As our entry point is traditional smallscale multi-species fisheries, we do not directly modify fishing effort by species but rather by fishing gear [48]. A change in the fishing effort of a given fishing gear affects first the total biomass of its harvested species and then is allocated between each species after fishing ratio from base year. 
Thanks to the EwE publication on the Gulf of Lion and included data on landings by gear and by species (Ibid.), we were able to distinguish 4 fishing gears: trawls, tuna seiner, lamparos (traditional kind of nighttime fishing using light to attract small pelagics), and other artisanal fishing gears. It does not include recreational fishing.

To spatialize fisheries, we do not associate each fishing gear with specific locations or habitats: fishing effort by fishing gear is the same all over the area, with two exceptions. The former refers to FPA areas where any kind of fishing is forbidden (Cerbère-Banyuls Natural Marine Reserve). The latter refers to trawls and artisanal fisheries whose activity is constrained by practical or legal concerns. First, it is known that artisanal fisheries work mostly near the coast up to a maximum distance of 6 nautical miles and a maximum depth of -200 meters. Second, trawls are prohibited between 0 and 3 nautical miles (2013 Trawl Management Plan). Here we do not model transfer effects between sites or towards new sites.

\section{Sea users. Diving.}

To model diving, we use a GIS layer indicating the most popular diving sites in the park. With each diving site, we associate an annual number of visitors that fits known trends. Here changes in diver attendance depend on the extent of fully protected areas prohibiting this practice. Here again we do not model transfer effects between sites or towards new sites.

Management. Fully protected areas (FPA).

To model FPA and access rights, we use a GIS layer indicating the boundaries of the existing FPA (CerbèreBanyuls Natural Marine Reserve). There fishing is prohibited.

To model the creation of new FPA, we target important natural areas. To do so, we use a GIS layer corresponding to a map from the park management plan that indicates important natural areas (see SM4). More precisely the map scales areas after their natural value using a "heat gradient" (see management plan for details). To reach the level of protection expected in each scenario, we downgrade every five years between 2020 and 2030 the level of natural value required to be designated as an FPA. Here these levels of natural value are chosen to get closer to the expected level of protection. Areas to be protected are designated after their natural value but rules of attribution slightly change among scenarios.

When protecting a large portion of the MPA (scenario 1, SM5), there is no need to target first a specific area: one is sure that all areas of great natural value will be included in the protected perimeter. Here we rather seek to make progress on the overall MPA and the only criterion to be designated protected area refers to the level of natural value.

When protecting a small portion of the MPA (scenario 2), one may want to make sure to protect consistent areas of great natural value rather than sparse micro hot points. To do so, we target the existing Marine Reserve and let new protected areas develop in its surroundings.

When protecting a medium portion of the MPA (scenario 3), we use a combination of the two previous rules: in 2020 we target the surroundings of the Marine Reserve to be sure to protect this area of greatest natural 
value while in 2025 and 2030 we also let protected areas develop elsewhere, after local level of natural value.

Concerning access right, fully protected areas were intended as "no go, no take" zones/integral reserves during the workshops. Thus, we prohibit fishing and diving in the corresponding perimeters.

\section{Management. Facilities planning \& ecological engineering.}

To model facilities planning, we select artificial reefs and floating wind turbines. We don't represent harbors and break walls as they were much likely associated with sea level rise during the workshops. This is a major issue but beyond the scope of this ecosystem-based modelling.

\section{Artificial reefs.}

To model artificial reefs, we use a GIS layer indicating their location and we assume that they are comparable to natural rocky reefs [58]. Thus, existing artificial reefs are associated with the same food-web as the Rock ecosystem cited above.

According to expert opinion, the occupancy rate of existing artificial reefs villages inside the park is around $12 \%$. To model their densification, we impose a steady annual increase in the biomass of each species until it reaches the equivalent of a $50 \%$ occupancy rate by 2050 .

To model the installation of new reefs in new villages, we replace a portion of sandy habitat with rocky habitat corresponding to an occupancy rate of $50 \%$. Then we describe a three steps colonization by marine organisms:

- a pioneer phase of 1 year with the development of phytoplankton, zooplankton, detritus, macroalgae and worms;

- a maturation phase of 2 to 5 years with the development of supra-benthos, gorgonians, benthic invertebrates, sea urchins, octopuses and bivalve gastropods;

- a completion phase after 5 years, with the development of salema, sparidae, seabream, conger, seabass, scorpion fish and picarel [58].

\section{Floating wind turbines.}

To model floating wind turbines, we create a GIS layer from a map used by the management team of the park to initiate debates with stakeholders on possible locations of already approved experimental turbines and possible new commercial ones. During the workshops and the project team meetings, two possible adverse effects of floating turbines on the ecosystem were discussed. Some figured the floating base and the anchorages would have a sort of "fish aggregating device" effect while the location area would be prohibited from fishing. Other thought antifouling paint would prevent such an effect while ultrasounds due to the functioning of turbines would trouble cetaceans. 
Here, we do not model these alternative effects because of time constraints and lack of scientific evidence and data to our knowledge. We model their possible progressive development every five years between 2020 and 2045 around the "overall" and "most acceptable" areas designated by the map using a propagation rule in the surroundings of already approved experimental turbines.

\section{Multi-purpose facilities.}

To model multi-purpose facilities, we add attendance indicators to artificial reefs and floating turbines in some cases.

In scenarios 2 and 3 , the development of a commercial wind farm is associated with the development of a touristic dedicated activity consisting in sea-visiting the area, explaining its purpose and possible effects on ecosystems. With each turbine, we associate an annual number of visitors deduced from assumptions on number of opening days by year, number of visits by day, number of passengers by visit. Here visitor attendance follows from the development of a commercial wind farm.

In scenario 3, a few artificial reefs are developed with both ecological and aesthetic concerns and are associated with the development of a dedicated diving activity. With each reef, we associate an annual number of divers deduced from assumptions on number of opening days by year, number of visits by day, number of divers by visit. Here visitor's attendance follows from recreational reefs development. Two aesthetic artificial reef villages are developed in 2025 and 2035.

Reintroduction of species.

To model the reintroduction of species, we focus respectively on one heritage species in scenario 1 (grouper) and on two commercial species in scenario 2 (seabass and dentex). Concerning sites of reintroduction, we target rocky ecosystem and specifically existing artificial reefs villages. Each year between 2020 and 2025, we repopulate from juveniles and adult individuals expressed in biomass equivalent. Here, priority is given to meeting the food needs of reintroduced species, corresponding to their estimated biomass levels, even if at the expense of the already established species. As biomass levels of reintroduced species are of the same order as those of top predators already represented in the rock ecosystem, this hypothetical situation calls for a later more complex representation of their competition for food.

\section{Declarations}

\section{Contributions}

All authors wrote and reviewed the main text. Elsa Mosseri and Xavier Lagurgue designed figures 1 and 2. Elsa Mosseri and Catherine Boemare designed figure 3. Catherine Boemare and Xavier Lagurgue designed figure 4. Elsaz Mosseri coded the agent-based model.

\section{Acknowledgements}


This work was supported by grants from the Fondation de France and Agence des Aires Marines Protégées, SAFRAN project. JC acknowledges financial support from BiodivERsA.

\section{Data availability}

The data that support the findings of this study are available in Supplementary materials.

\section{Code availability}

The code that supports the finding of this study is available on GitHub at :

https://github.com/elsamosseri/SAFRAN

\section{References}

1. Laffoley, D., Baxter, J.M., Amon, D.J., Claudet, J., Hall-Spencer, J.M., Grorud-Colvert, K., Levin, L.A., Reid, P.C., Rogers, A.D., Taylor, M.L., et al. Evolving the narrative for protecting a rapidly changing ocean, postCOVID-19. Aquat. Conserv. Mar. Freshw. Ecosyst. aqc.3512 (2020).

2. Lubchenco, J., Grorud-Colvert, K.. Making waves: The science and politics of ocean protection. Science 350 (6259), 382-383 (2015).

3. Ban Natalie C.\& al. Well-being outcomes of marine protected areas. Nature sustainability $2,524-532$ (2019).

4. Horta e Costa et al. A regulation-based classification system for Marine Protected Areas (MPAs). Mar.Policy 72, 192-198 (2016).

5. Sala, E., and Giakoumi, S. No-take marine reserves are the most effective protected areas in the ocean. ICES Journal of Marine Science 75, 1166-1168 (2017).

6. Zupan, M., Fragkopoulou, E., Claudet, J., Erzini, K., Horta e Costa, B., and Goncalves, E.J. Marine partially protected areas: drivers of ecological effectiveness. Front. Ecol. Environ. 16, 381-387 (2018).

7. Claudet, J., C. Loiseau, M. Sostres, M. Zupan. Underprotected Marine Protected Areras in a Global Biodiversity Hotspot. One Earth 2, 380-384 (2020).

8. Claudet, J. The seven domains of action for a sustainable Ocean. Cell, Elsevier, 184 (6), 1426-1429 (2021). 10.1016/j.cell.2021.01.055 . hal-03177726

9. Hutton, J. M. et Leader-Williams, N. Sustainable use and incentive-driven conservation: realigning human and conservation interests. Oryx 37(2), 215-226 (2003).

10. Sala, E., Mayorga, J., Bradley, D. et al. Protecting the global ocean for biodiversity, food and climate. Nature 592, 397-402 (2021). https://doi.org/10.1038/s41586-021-03371-z

11. Thiault L, Gelcich S, Marshall N, Marshall P, Chlous F, Claudet J. Operationalizing vulnerability for socialecological integration in conservation and natural resource management. Conservation Letters.13:e12677 (2020).

12. Young, O., Berkhout, F., Gallopin, G., Janssen, M., Ostrom, E., Vanderleeuw, S. The globalization of socioecological systems: an agenda for scientific research. Glob. Environ. Change 16 (3), 304e316 (2006). 
13. Liu, J.G., Dietz, T., Carpenter, S.R., Alberti, M., Folke, C., Moran, E., Pell, A.N., Deadman, P., Kratz, T., Lubchenco, J., Ostrom, E., Ouyang, Z., Provencher, W., Redman, C.L., Schneider, S.H., Taylor, W.W. Complexity of coupled hu- man and natural systems. Science 317 (5844), $1513 \mathrm{e} 1516$ (2007).

14. Cinner, J.E., McClanahan, T.R., Daw, T.M., Graham, N.A.J., Maina, J., Wilson, S.K., Hughes, T.P. Linking social and ecological systems to sustain coral reef fisheries. Curr. Biol. 19 (3), $206 \mathrm{e} 212$ (2009).

15. Chapin, F.S., Carpenter, S.R., Kofinas, G.P., Folke, C., Abel, N., Clark, W.C., Olsson, P., Smith, D.M.S., Walker, B., Young, O.R., Berkes, F., Biggs, R., Grove, J.M., Naylor, R.L., Pinkerton, E., Steffen, W., Swanson, F.J. Ecosystem steward- ship: sustainability strategies for a rapidly changing planet. Trends Ecol. Evol. 25 (4), 241e249 (2010).

16. Diaz, S., Quetier, F., Caceres, D.M., Trainor, S.F., Perez-Harguindeguy, N., Bret- Harte, M.S., Finegan, B., Pen a-Claros, M., Poorter, L. Linking functional diversity and social actor strategies in a framework for interdisciplinary analysis of nature's benefits to society. Proc. Natl. Acad. Sci. USA 108 (3), $895 e 902$ (2011).

17. Leenhardt P, Teneva L, Kininmonth S, Darling E, Cooley S, Claudet J. Challenges, insights and perspectives associated with using social-ecological science for marine conservation. Ocean Coast Manag. 115, 49-60 (2015).

18. Étienne, M. (Ed.). Companion modelling: a participatory approach to support sustainable development (Quae \& Springer Science, 2013). The companion modelling approach, https://www.commod.org/en.

19. Schuwirth, N., Borgwardt, F., Domisch, S., Friedrichs, M., Kattwinkel, M., Kneis, D., Kuemmerlen, M., Langhans, S.D., Martinez-Lopez, J., Vermeiren, P. How to make ecological models useful for environmental management. Ecological Modelling 411, 1-12 (2019).

20. Sen, S., and Nielsen, J.R. Fisheries co-management: a comparative analysis. Marine Policy 20, $405-418$ (1996).

21. Martin-Smith, K.M., Samoilys, M.A., Meeuwig, J.J. and Vincent, A. C. J. Collaborative development of management options for an artisanal fishery for seahorses in the central Philippines. Ocean and Coastal Management 47, 165-193 (2004).

22. Verheij, E., Makoloweka, S., Kalombo, H. Collaborative coastal management improves coral reefs and fisheries in Tanga, Tanzania. Ocean and Coastal Management 47, 309-320 (2004).

23. Hartley, T. W. and Robertson, R.A. Emergence of multistakeholder-driven cooperative research in the Northwest Atlantic: the case of the Northeast Consortium. Marine Policy 30, 580-592 (2006).

24. Kitts, A., Pinto da Silva, P., Rountree, B. The evolution of collaborative management in the Northeast USA tilefish fishery. Marine Policy 31, 192-200 (2007).

25. Cheong, S. A new direction in coastal management. Marine Policy 32 (6), 1090-1093 (2008).

26. Davis, N.A. Evaluating collaborative fisheries management planning: a Canadian case study. Marine Policy 32, 867-876 (2008).

27. Costello, C., Gaines S.D. and Lyman, J. Can catch shares prevent fisheries collapse? Science 371, 16781681 (2008).

28. Wendt, D.E. \& Starr, R. M. Collaborative research: an effective way to collect data for stock assessments and evaluate marine protected areas in California. Marine and Coastal Fisheries: Dynamics, 
Management, and Ecosystem Science 1, 315-324 (2009).

29. Wyborn, C., F. Davila, L. Pereira, M. Lim, I. Alvarez, G. Henderson, A. Luers, M. J. Martinez Harms, K. Maze, J. Montana, M. Ryan, C. Sandbrook, R. Shaw \& E. Woods, 2021. Imagining transformative biodiversity futures, Nat. Sustain. 3, 670-672 (2021).

30. Leslie, H. M., and McLeod K.L. Confronting the challenges of implementing marine ecosystem-based management. Frontiers in Ecology and the Environment 5, 540-548 (2007).

31. Spijkers et al., 2021. Exploring the future of fishery conflict through narrative scenarios, One Earth 4, 386-396 (2021), https://doi.org/10.1016/j.oneear.2021.02.004

32. Lubchenko, J., and Gaines, S.D. A new narrative for the ocean. Science 364, 911 (2019)

33. McLeod, K. L., J. Lubchenco, S. R. Palumbi, and A. A. Rosenberg. Scientific Consensus Statement on Marine Ecosystem-Based Management. Signed by 217 academic scientists and policy experts with relevant expertise and published by the Communication Partnership for Science and the Sea at http://compassonline.org/?q=EBM (2005).

34. Cury, P., Shannon, L. \& Shin, Y.J. The functioning of the marine ecosystems: a fisheries perspective. In Responsible fisheries in the marine ecosystem (M. Sinclair \& G. Valdimarsson, eds) 103-123 (Rome, Italy, and Wallingford, UK. FAO and CAB International, 2003).

35. Anderies, J. M., O. Barreteau, U. Brady. Refining the robustness of socio-ecological systems framework for comparative analysis of coastal system adaptation to global change. Regional Environmental Change 19, 1891-1908 (2019).

36. Lester, S.E., Halpern, B.S., Grorud-Colvert, K., Lubchenco, J. and others. Biological effects within no-take marine re- serves: a global synthesis. Mar Ecol Prog Ser 384, 33-46 (2009).

37. Guizien, K., Belharet, M., Moritz, C., and Guarini, J. M. Vulnerability of marine benthic metapopulations: implications of spatially structured connectivity for conservation practice in the Gulf of Lions (NW Mediterranean Sea). Diversity and Distributions 20 (12), 1392-1402 (2014).

38. Cabral, R.B., S. Gaines, B. A. Johnson, T. W. Bell, and C. White. Drivers of redistribution of fishing efforts and non-fishing efforts after the implementation of a marine protected area network, Ecological Applications 27 (2), 416-428 (2017).

39. Travers, M., Shin, Y.-J., Jennings, S., Cury, P. Towards end-to-end models for investigating the effects of climate and fishing in marine ecosystems. Progress in Oceanography 75(4), 751-770 (2007).

40. Mahevas, S., Pelletier, D. ISIS-Fish, a generic and spatially explicit simulation tool for evaluating the impact of management measures on fisheries dynamics. Ecological modelling 171(1-2), 65-84 (2004).

41. Pelletier, D. et al. Evaluation of the bioeconomic sustainability of multi-species multi-fleet fisheries under a wide range of policy options using ISIS-Fish. Ecological Modelling 220(7), 1013-1033 (2009).

42. Provot, Z. et al. Using a quantitative model for participatory geo-foresight: ISIS-Fish and fishing governance in the Bay of Biscay. Marine Policy 117 (2020).

43. Heymans, J.J., M. Coll, J.S. Link, S. Mackinson, J. Steenbeek, C. Walters, W. Christensen. Best practice in Ecopath with Ecosim foodweb models for Ecosystem-based management. Ecological Modelling, 331, 173-184 (2016). 
44. Bourdaud, P. Impact d'une obligation de débarquement sur les dynamiques couplées écosystèmepêcheurs: approche par modélisation individu-centrée appliquée à la Manche Orientale (Université du Littoral Côte d'Opale, 2018).

45. Personnic, S. et al. An ecosystem-based approach to assess the status of a Mediterranean ecosystem, the Posidonia oceanica seagrass meadow. PloS one 9(6), (2014).

46. Ruitton, S. et al. An ecosystem-based approach to assess the status of the Mediterranean coralligenous habitat. In RAC/SPA 2nd Mediterranean Symp. on the Conservation of coralligenous and other calcareous bio-concretions 2, 153-158 (2014).

47. Thibaut, T. et al. An ecosystem-based approach to assess the status of Mediterranean algae-dominated shallow rocky reefs. Marine pollution bulletin 117(1-2), 311-329 (2017).

48. Bănaru D., C. Mellon-Duval D. Roos, J.-L. Bigot, A. Souplet, A. Jadaud, P. Beaubrun, J.-M. Fromentin. Trophic structure in the Gulf of Lions marine ecosystem (north-western Mediterranean Sea) and fishing impacts. Journal of Marine Systems 111-112, 45-68 (2013).

49. Corrales X., D. Vilas, C. Piroddi, J. Steenbeek, J. Claudet, J. Lloret, A. Calo, A. Di Franco, T. Font, A. Ligas, G. Prato, R. Sahyoun, P. Sartor, P; Guidetti, M. Coll. Multi-zone marine protected areas: Assessment of ecosystem and fisheries benefits using multiple ecosystem models. Ocean and Coastal Management, 193, 105232, (2020) ISSN 0964-5691, https://doi.org/10.1016/j.ocecoaman.2020.105232.

50. http://isidoredd.documentation.developpement-durable.gouv.fr/document.xsp?id=Temis-0084332

51. Bousquet, F., O. Barreteau, C. Le Page, C. Mullon, J. Weber. An environmental modelling approach: the use of multi-agent simulations, in Advances in environmental and ecological modelling (ed. Blasco F.) 113-122 (Elsevier, 1999, Paris).

52. Bousquet, F. et C., Le Page. Multi-agent simulations and ecosystem management: a review, Ecological Modelling 176, 313-332 (2004).

53. https://ccl.northwestern.edu/netlogo/docs/tutorial1.html

54. Ferber, J. Multi-Agent Systems. An Introduction to Distributed Artificial Intelligence (Addison Wesley, 1999).

55. Wooldridge, M. An introduction to multiagent systems (John Wiley \& Sons, 2009).

56. Bopp, L., Resplandy, L., Orr, J. C., Doney, S. C., Dunne, J. P., Gehlen, M., Halloran, P., Heinze, C., llyina, T., Séférian, R., Tjiputra, J., and Vichi, M. Multiple stressors of ocean ecosystems in the 21st century: projections with CMIP5 models, Biogeosciences 10, 6225-6245 (2013), https://doi.org/10.5194/bg-106225-2013.

57. Bindoff, N.L., W.W.L. Cheung, J.G. Kairo, J. Arístegui, V.A. Guinder, R. Hallberg, N. Hilmi, N. Jiao, M.S. Karim, L. Levin, S. O'Donoghue, S.R. Purca Cuicapusa, B. Rinkevich, T. Suga, A. Tagliabue, and P. Williamson. Changing Ocean, Marine Ecosystems, and Dependent Communities. In: IPCC Special Report on the Ocean and Cryosphere in a Changing Climate [H.-O. Pörtner, D.C. Roberts, V. Masson-Delmotte, P. Zhai, M. Tignor, E. Poloczanska, K. Mintenbeck, A. Alegría, M. Nicolai, A. Okem, J. Petzold, B. Rama, N.M. Weyer (eds.)].

58. Tessier A., P. Francour, E. Charbonnel, N. Dalias, P. Bodilis, W. Seaman, P. Lenfant. Assessment of French artificial reefs: due to limitations of research, trends may be misleading, Hydrobiologia, 753, 1-29 
(2015).

59. Lotze, H. K., H. S. Lenihan, B. J. Bourque, R. H. Bradbury, R. G. Cooke, M. C. Kay, S. M. Kidwell, M. X. Kirby, C. H. Peterson, J. B. C. Kackson. Depletion, Degradation, and Recovery Potential of Estuaries and Coastal Seas, Science 312, 1806-1809 (2006).

60. Duarte, C.M., Conley, D.J., Carstensen, J. et al. Return to Neverland: Shifting Baselines Affect

Eutrophication Restoration Targets. Estuaries and Coasts 32, 29-36 (2009). https://doi.org/10.1007/s12237-008-9111-2

61. Pauly D. Anecdotes and the shifting baseline syndrome of fisheries. Trends Ecol Evol. 10(10)430 (1995). doi: 10.1016/s0169-5347(00)89171-5.

62. Pinnegar, J.K. and G.H. Engelhard. The 'shifting baseline' phenomenon: a global perspective, Rev Fish Biol Fisheries, 18 1-16 (2008). DOI 10.1007/s11160-007-9058-6

63. Duarte, C. M., S. Agusti, E. Barbier, G. L. Britten, J. C. Castilla, J.P. Gattuso, R. W. Fulweiler, T. P. Hughes, N. Knowlton, C. E. Lovelock, H. K. Lotze, M. Predragovic, E. Poloczanska, C. Roberts and B. Worm. Rebuilding marine life. Nature 580, 39-51 (2020). doi: 10.1038/s41586-020-2146-7.

64. Barbault, R. Un éléphant dans un jeu de quilles (Seuil, 2006).

65. Lotze, H. K., M. Coll, A. M. Magera, C. Ward-Paige and L., Airoldi. Recovery of marine animal populations and ecosystems, Trends in Ecology and Evolution 26(11), 595-605 (2011).

66. Millenium Ecosystem Assessment. Ecosystem and human well-being: synthesis. Island Press, Washington, D.C. (2005)

67. Pauly, D., and W., Christensen. Primary production required to sustain global fisheries. Nature 374, 255257 (1995).

\section{Figures}



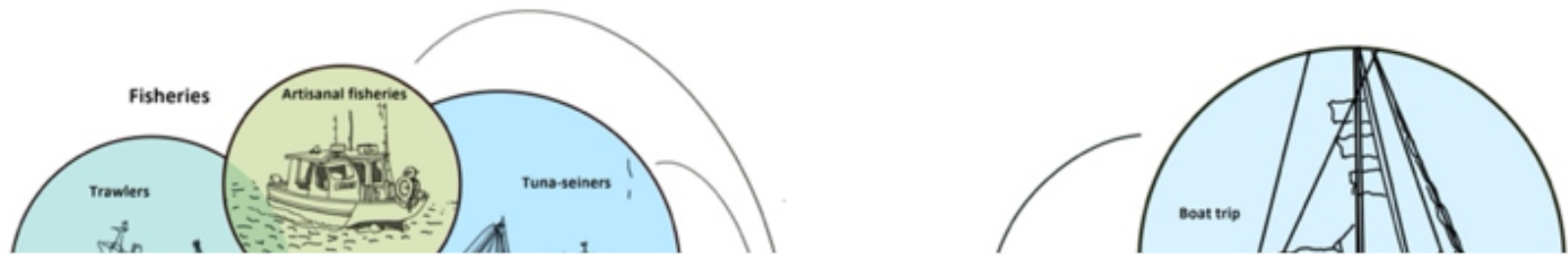

Figure 1

The Gulf of Lions marine protected area social-ecological system. 


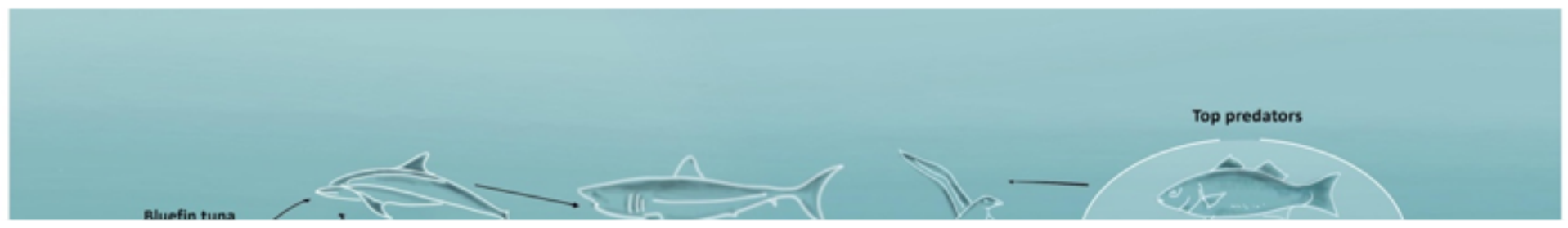

Figure 2

The Gulf of Lions marine protected area food web 

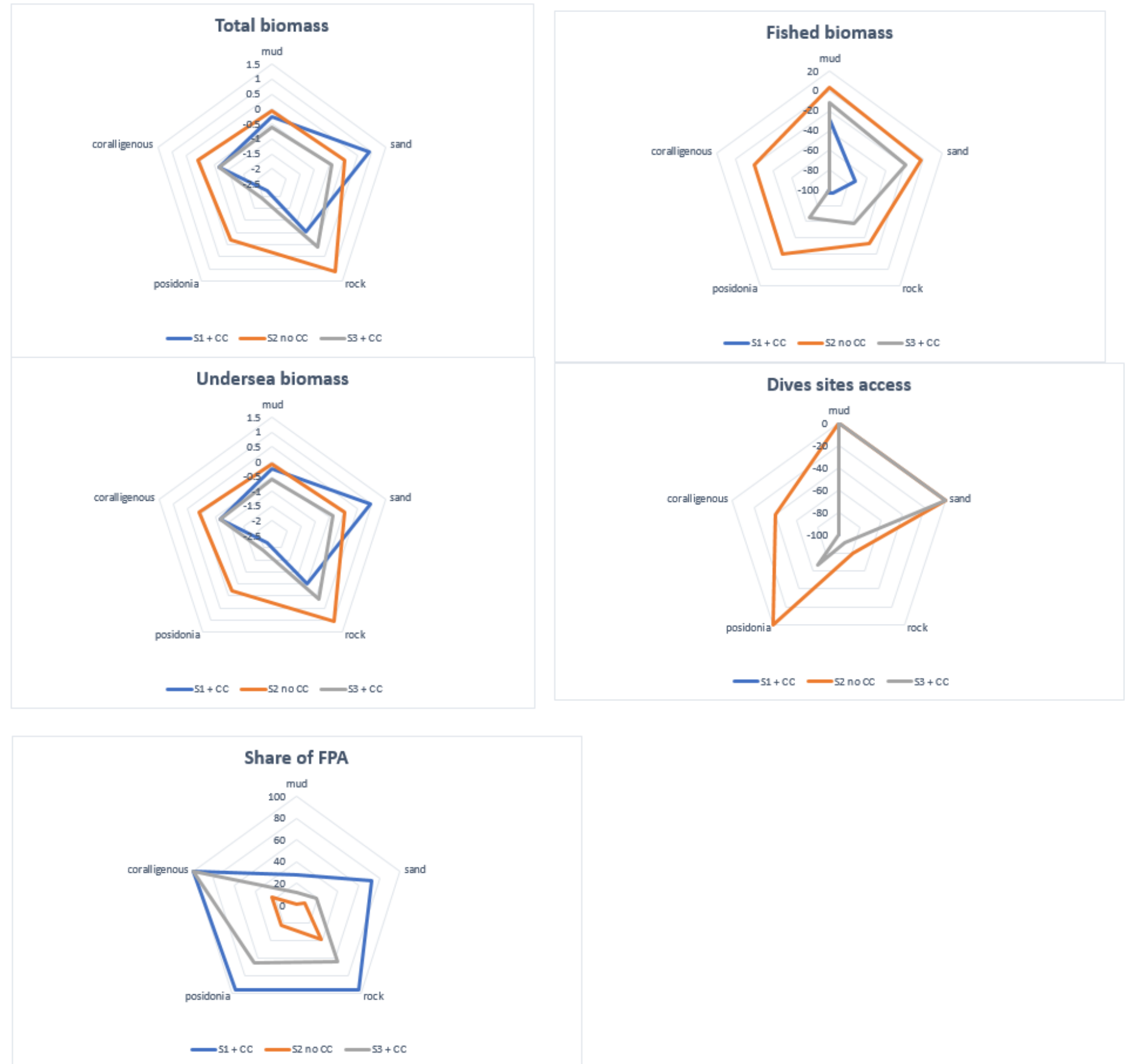

\section{Figure 3}

Simulation results for the three scenarios S1, S2, S3

SI + CC: enhancing regulating services with primary production decreasing due to climate change

S2 no CC: enhancing provisioning services without primary production decreasing

S3 + CC: enhancing cultural services with primary production decreasing due to climate change 


\section{Pre-requisite}

Aim

Agreeing collectively on main issues

Outcome

Representing the territory as a SES

Mean

Conducting workshop around a chronological matrix which outlines the main features of the territory



Figure 4

Flowchart illustrating the key steps of the framework proposed

\section{Supplementary Files}

This is a list of supplementary files associated with this preprint. Click to download.

- BoemareCnpjOceanSustainabilitySupplementaryMaterials02032022.docx 